\title{
RESEARCH
}

Open Access

\section{Biological control of bacterial wilt in tomato through the metabolites produced by the biocontrol fungus, Trichoderma harzianum}

Liu Yan ${ }^{1 *}$ and Raja Asad Ali Khan ${ }^{2^{*}}$ (D)

\begin{abstract}
Background: Ralstonia solanacearum causes bacterial wilt disease in tomato and other crops resulting in huge economic losses worldwide. Several measures have been explored for the control of $R$. solanacearum, but the desired control level of the disease through sustainable and ecofriendly way is still awaited.

Main body: In this study, fungal metabolites produced by Trichoderma harzianum were investigated in the form of crude extract for the management of $R$. solanacearum both in vitro and in planta in tomato plants. In in vitro investigation, fungal metabolites were checked for their antibacterial potential at different concentrations (30, 60, $90,120,150$, and $180 \mathrm{mg} \mathrm{ml}^{-1}$ ) and bacterial cell morphology was observed under scanning electron microscopy (SEM). In a greenhouse experiment, different application times ( 0,3 , and 6 days before transplantation DBT) and doses $(0,3,6$, and $9 \%)$ of the fungal metabolites were tested for their effects on soil bacterial population, disease severity and plant growth of tomato plants. The in vitro evaluation showed a strong antibacterial activity of fungal metabolites in concentration dependent manner. The highest concentration $180 \mathrm{mg} \mathrm{ml}^{-1}$ produced maximum inhibition zone $(20.2 \mathrm{~mm})$ having non-significant difference with the inhibition zone $(20.5 \mathrm{~mm})$ produced by the standard antibiotic streptomycin. The SEM analysis revealed severe morphological destructions of bacterial cells. In case of greenhouse experiment, the highest decrease in soil bacterial population, lowest disease severity, and maximum increase in plant growth parameters were obtained by highest dose (9\%) and longest application time (6 DBT).
\end{abstract}

Conclusion: The fungal metabolites produced by T. harzianum could be used as low-cost, environment-friendly, and sustainable management strategy for the control of $R$. solanacearum in tomato plants.

Keywords: Trichoderma harzianum, Biological control, Tomato, Bacterial wilt, In vitro, In planta

\footnotetext{
* Correspondence: ly78210310@sina.com; asadraja@aup.edu.pk

${ }^{1}$ College of Life Sciences, Changchun Sci-Tech University, ChangChun 130000, P.R. China

${ }^{2}$ Institute of Vegetables and Flowers, Chinese Academy of Agricultural

Sciences, Beijing, P.R. China
}

\section{Springer Open}

(c) The Author(s). 2021 Open Access This article is licensed under a Creative Commons Attribution 4.0 International License, which permits use, sharing, adaptation, distribution and reproduction in any medium or format, as long as you give appropriate credit to the original author(s) and the source, provide a link to the Creative Commons licence, and indicate if changes were made. The images or other third party material in this article are included in the article's Creative Commons licence, unless indicated otherwise in a credit line to the material. If material is not included in the article's Creative Commons licence and your intended use is not permitted by statutory regulation or exceeds the permitted use, you will need to obtain permission directly from the copyright holder. To view a copy of this licence, visit http://creativecommons.org/licenses/by/4.0/. 


\section{Background}

Tomato (Lycopersicon esculentum L.), a vegetable crop cultivated commercially throughout the world, is one of the most consumed vegetable. Because of its perennial cultivation on large scale and perishable nature, it is susceptible to several plant pathogens that cause poor yield in different countries as a result of undesirable physiological and biological changes (Tajul et al. 2011). Among plant pathogens, the phytopathogenic bacteria are one of the main constraints on tomato yield and production. Ralstonia solanacearum is a $\mathrm{G}^{-}$bacterium, which is considered as one of the highly destructive pathogens. It is distributed worldwide and has significant economic impact globally (Scherf et al. 2010). It is a pathogen of many plants, causes wilting disease and especially more destructive to tomato plants, leading to substantial losses in tropical and other regions with warm temperature (Huet 2014).

$R$. solanacearum can spread by flooding or irrigation, agricultural equipment, weeds, workers, and soil. The pathogen can use weeds, infected plants and plant debris for its survival. Wide host range, complication in biology and nature of infestation and other factors make its management difficult (Aloyce et al. 2017). Mainly, chemical control and resistant varieties are used for its management. However, utilization of resistant varieties has not always been beneficial as in some cases the resistance of the plants obtained by resistant varieties negatively correlated with yield (Yuliar and Toyota 2015). Additionally, the resistance is usually strain-specific. Use of chemicals is not desirable because of serious environmental, human, and animal health hazards. Also, bacterial resistance to these chemicals was reported $(\mathrm{McD}$ Donald and Linde 2002). Recently, some other measures have been explored for the control of $R$. solanacearum but the desired control level of the disease through sustainable and ecofriendly way is still awaited. Therefore, the use of integrated management strategy combining cultural practices, biologic control, and host plant resistance appears to be more effective. Although, for the control of bacterial wilt disease in different crops, several attempts were made in the area of biological control with varied levels of success but there is still a great opportunity to provide a stable solution to this problem (Bailey and Lazarovits 2003). The use of biological control agents or their antimicrobial products is a consumer and environment friendly approach for managing the plant disease (Hyde and Soytong 2008). Fungal metabolites present in the crude extract produced by biocontrol fungus may have an antimicrobial potential against several plant pathogens (Mohamed et al. 2020; Konappa et al. 2020). Among biocontrol fungi, the genus Trichoderma comprises many effective biocontrol agents against plant pathogens. Because of their ability to produce a variety of secondary metabolites, these fungi are now the center of attention for many researchers (Kariuki et al. 2020; Konappa et al. 2020). The ability to promote growth and induce resistance in plants has also been described for members of this genus (Monte 2001). Among Trichoderma spp. several antibacterial secondary metabolites such as lysosime, viridiofungin, and trichokonin were isolated from $T$. harzianum. These compounds showed an antibacterial activity against bacterial plant pathogens such as Clavibacter michiganensis and Erwinia amylovora (El-Hasan et al. 2009). Although, the antibacterial activity of fungal metabolites from this fungus was reported against some plant bacterial pathogens, but its antibacterial evaluation was done only in vitro studies in labs. Moreover, this fungus was not evaluated specifically against $R$. solanacearum.

This study aimed to find the potential of fungal metabolites of $T$. harzianum for the management of bacterial wilt disease in tomato plants both in vitro and in planta. The study was also extended to investigate the effect of fungal metabolites on morphological destruction of bacterial cells through scanning electron microscopy (SEM).

\section{Materials and methods}

Fungal and bacterial cultures

The pure culture of $T$. harzianum and phytopathogenic bacteria, i.e., $R$. solanacearum, that were already identified through PCR amplification and preserved at -80 ${ }^{\circ} \mathrm{C}$, were obtained from the Institute of Vegetables and Flowers, Chinese Academy of Agricultural Sciences (Khan et al. 2020). Fresh culturing of the fungus and bacteria was carried out on PDA (potato dextrose agar) incubated at $28{ }^{\circ} \mathrm{C}$ for 7-10 days and LB media incubated at $28{ }^{\circ} \mathrm{C}$ for $1-2$ days, respectively.

\section{Fungal metabolites preparations}

Freshly prepared fungus was grown on wheat media for obtaining fungal metabolites in the form of crude extract. At first, seed media of the fungus was prepared by inoculating 5 plugs of fungal culture in to seed media (Bacto neopeptone $10 \mathrm{~g}$, Maltose $40 \mathrm{~g}$, Yeast extract 10 g, and Agar $4 \mathrm{~g} / \mathrm{L}$ ) in $500 \mathrm{ml}$ flask. Each flask was containing $100 \mathrm{ml}$ of seed media. The seed media obtained after shaking incubation for 4 days at $25{ }^{\circ} \mathrm{C}$ was inoculated to sterilized wheat at $5 \mathrm{ml} / 30 \mathrm{~g}$ of wheat in $500 \mathrm{ml}$ flasks. The flasks were incubated for 14 days and stationary at $25^{\circ} \mathrm{C}$. After 14 days, the $150 \mathrm{ml}$ of extraction solvent ethyl acetate was added to each flask and kept as such for half hour. The solvent layer containing fungal metabolites was separated and evaporated under reduced pressure for the collection of fungal metabolites (Vizcaino et al. 2006). The collected fungal metabolites were preserved at $4{ }^{\circ} \mathrm{C}$ after complete dry and use for in vitro and in planta experiments. 
In vitro antibacterial evaluation of fungal metabolites Agar well-diffusion test

Agar well diffusion test was conducted for examining the antibacterial potential of fungal metabolites against $R$. solanacearum (Tong et al. 2018). Different concentrations, i.e., $30,60,90,120,150$, and $180 \mathrm{mg} \mathrm{ml}^{-1}$ of fungal metabolites were prepared by dissolving in methanol and checked for their activity. Briefly, a total of 8 uniform size wells were punched in a sterilized plastic Petri plate having $25 \mathrm{ml} \mathrm{LB}$ medium mixed with $0.5 \mathrm{ml}$ bacterial suspension $\left(10^{8} \mathrm{cfu}\right)$. Six wells were poured with different concentrations $(30,60,90,120,150$, and 180 $\mathrm{mg} \mathrm{ml}^{-1}$ ) of fungal metabolites at the rate of $10 \mu \mathrm{l}$ per well. Two wells, one poured with $10 \mu \mathrm{l}$ of standard antibiotic streptomycin, and one with $10 \mu \mathrm{l}$ of methanol, were used as positive and negative controls, respectively. The antibacterial activity was checked by measuring the zone of growth inhibition (ZI) for each treatment after incubation for $24 \mathrm{~h}$ at $28{ }^{\circ} \mathrm{C}$. The test was performed in triplicate and mean values were presented in results.

\section{SEM study of bacterial cell}

Scanning electron microscopy (SEM) of bacterial cells without treatment and treated with fungal metabolites was conducted for the conformation of antibacterial effect of fungal metabolites and to observe the morphological destruction. For the preparation of samples, small agar pieces of agar were cut out from the inhibition zone of best treatment and from untreated control. The agar pieces were than fixed in $2.5 \%(\mathrm{v} / \mathrm{v})$ glutaraldehyde (in phosphate buffer) at $40{ }^{\circ} \mathrm{C}$ for $1 \mathrm{~h}$. Using phosphate buffer, the agar pieces were washed for $10 \mathrm{~min}$ and fixed for $2 \mathrm{~h}$ with $1 \%(\mathrm{w} / \mathrm{v})$ osmium tetroxide $\left(\mathrm{OsO}_{4}\right)$. Afterwards, the samples were washed 3 times in phosphate buffer dehydrated for $15 \mathrm{~min}$ in each graded ethanol series, i.e., $30,50,70,90$, and $95 \%$ and then they were subjected to $100 \%$ ethanol and $\mathrm{CO}_{2}$ to get the critical point. The samples were used for SEM observations after coating with (Kamonwannasit et al. 2013).

\section{In planta antibacterial evaluation of fungal metabolites Greenhouse test}

In planta antibacterial potential of fungal metabolites was evaluated for the control of bacterial wilt in tomato through pot experiment in screen house. Stem-sterilized soil at $1 \mathrm{~kg} \operatorname{pot}^{-1}$ was filled in plastic pots of $15 \mathrm{~cm}$ diameter. Uniform size (25 days old) and healthy tomato seedlings were transplanted to each pot at 1 seedling $\operatorname{pot}^{-1}$. For the initiation of bacterial wilt disease, soil in each pot at the center was inoculated with $35 \mathrm{ml}$ of $R$. solanacearum suspension $\left(10^{8} \mathrm{cfu}\right)$ (Najeeb et al. 2019). Different concentrations, i.e., $0,3,6$, and $9 \% \mathrm{w} / \mathrm{v}$, of fungal metabolites at $10 \mathrm{ml} \mathrm{pot}^{-1}$ were applied at rhizosphere of each plant 3 days after the inoculation with pathogenic bacteria. The treatments were applied at 3 application times, i.e., 0,3 , and 6 days before transplantation (DBT). Horticultural recommendations were followed uniformly for fertilizer and irrigation requirements. The experiment was repeated concurrently with no modification with 5 replications for each treatment. After 60 days of transplantation, the experiment was terminated and data on growth parameters such as root length, plant height and fresh biomass, soil bacterial population, and disease severity were recorded.

\section{Area under disease progressive curve (AUDPC)}

Disease severity was measured by using a specific plant wilting scale. Different stages of wilting were presented by different categories of this scale: 1 , without symptoms; 2, wilting of less than half foliage; 3 , wilting of half foliage; 4 , wilting of all foliage; and 5 , wilting and death of whole plant. By using formula DS $\%=\left(\sum \mathrm{n} / 5 \mathrm{~N}\right) \times 100$ (Abdel-Monaaim et al. 2011). Where $\sum \mathrm{n}$ represents the summation of ratings of all plants scored, i.e., $\Sigma(1 \mathrm{~A}+$ $2 B+3 C+4 D+5 E)$, where $A, B, C, D$, and $E$ are the numbers of the plants of categories $1,2,3,4$, and 5 , respectively. $N$ is the total number of plants and 5 is the highest category of scale. The disease severity data, taken at 12 days interval, were converted to AUDPC value by using formula AUDPC $\left.=\sum \mathrm{n}=0(\mathrm{Xi}+1+\mathrm{Xi}) / 2\right)(\mathrm{Ti}+1$ - Ti). Where $n=$ total number of assessments, $\mathrm{Ti}=$ time at $i$ th assessment, and $\mathrm{Xi}=$ infection expressed in quantity at the $i$ th assessment (Madden et al. 2007).

\section{Soil population of $R$. solanacearum}

Four samples of soil cores were collected from each pot at the depth of 10-12 cm. A composite sample was made by mixing all the soil cores from the same treatment (Gruter et al. 2006). From the composite sample, 3 sub-samples were taken and serially diluted up to $10^{-7}$ separately. From 3 serially diluted sub-samples, $100 \mu \mathrm{l}$ from each was poured on TZCNA selective medium plate separately (Goszczynska et al. 2000). The plates were incubated for $48 \mathrm{~h}$ at $28{ }^{\circ} \mathrm{C}$. After incubation, bacterial colonies with off-white color and red center were counted, and soil bacterial population was calculated as $\mathrm{cfu} \mathrm{g}^{-1}$ of soil. The data were expressed as $\log \mathrm{cfu} / \mathrm{g}$ of soil.

\section{Statistical analysis}

Data were presented as mean \pm standard deviation. Statistical analysis was done using IBMSPSS Statistix 20 software. Completely randomized design (CRD) was applied to in vitro data, while factorial arrangements with 2 factors was used to analyze the in planta data. In case of significant differences, the means for treatments were 
separated by using alphabet lettering after applying Fisher's protected LSD test (Gomez and Gomez 1984).

\section{Result and discussion In vitro study}

The fungal metabolites were evaluated in different concentrations for their antibacterial potential against $R$. solanacearum. Results revealed the strong activity of fungal metabolites in concentration dependent manner (Fig. 1). Generally, increase in concentration resulted in higher activity. The highest concentration $180 \mathrm{mg} \mathrm{ml}^{-1}$ showed the largest IZ $(20.2 \mathrm{~mm})$, followed by $(19.8 \mathrm{~mm})$ produced by next lower concentration $150 \mathrm{mg} \mathrm{ml}^{-1}$. Notably, the inhibition zone produced by highest concentration of fungal extract was similar to the inhibition zone $(20.5 \mathrm{~mm})$ produced by the standard antibiotic streptomycin used as a positive control. The lowest two concentrations, i.e., 30 and $60 \mathrm{mg} / \mathrm{ml}$ and negative control methanol did not show antibacterial activity, and no inhibition zone was recorded at these treatments. Among different mechanisms of actions reported for Trichoderma spp. against plant pathogens, the secretion of biologically active metabolite is an important one (Gal-hemed et al. 2011). The antibacterial activity could be attributed to the antibacterial compounds present in crude extract. Several antimicrobial compounds were isolated from Trichoderma spp. against plant pathogens. For example, lysosime, the metabolite produced $T$. harzianum-controlled Clavibacter michiganensis (Utkhede and Koch 2004). El-Hasan et al. (2009) reported antibacterial effect of viridiofungin-A produced $T$. harzianum
T23 against C. michiganensis and Erwinia amylovora. Suppression of bacterial growth by peptaibol metabolites, i.e., Trichokonin VI, VII produced by Trichoderma spp. was reported by Xiao-yan et al. (2006).

\section{Morphological observation of bacterial cell}

SEM helped to study the morphological destruction of bacterial cells. A clear distinction was seen between the treated and untreated bacterial cells. The electron micrographs of bacterial cells were presented in Fig. 2. The bacterial cells under the influence of fungal metabolites showed a huge destruction in its morphology. The cell wall degradation, dis-integration of membranes, and leaking of cell content can be observed easily. While in comparison to treated and infected cells, the untreated cells displayed a characteristic uniform rod shape of the bacterium without any disturbance. Different bioactive and toxic compounds affect bacteria in different ways. Flavonoids compounds cause coagulation of cellular proteins and enzymes (Al-Obaidi 2014). Alkaloid compounds by acting as DNA intercalating agents and causing enzyme inhibition damage cell multiplication (Tanaka et al. 2006). Inhibition of nucleic acid and cell wall synthesis and membrane disruption are also reported in several studies (Zhang et al. 2008). Saito et al. (2019) reported that lysosime can disrupt the bacterial membranes, causes leakage of cell contents, which consequently causes cell death. The SEM analysis in this study confirmed these mechanisms as the micrographs showed sever membranes disruptions under the influence of fungal metabolites.

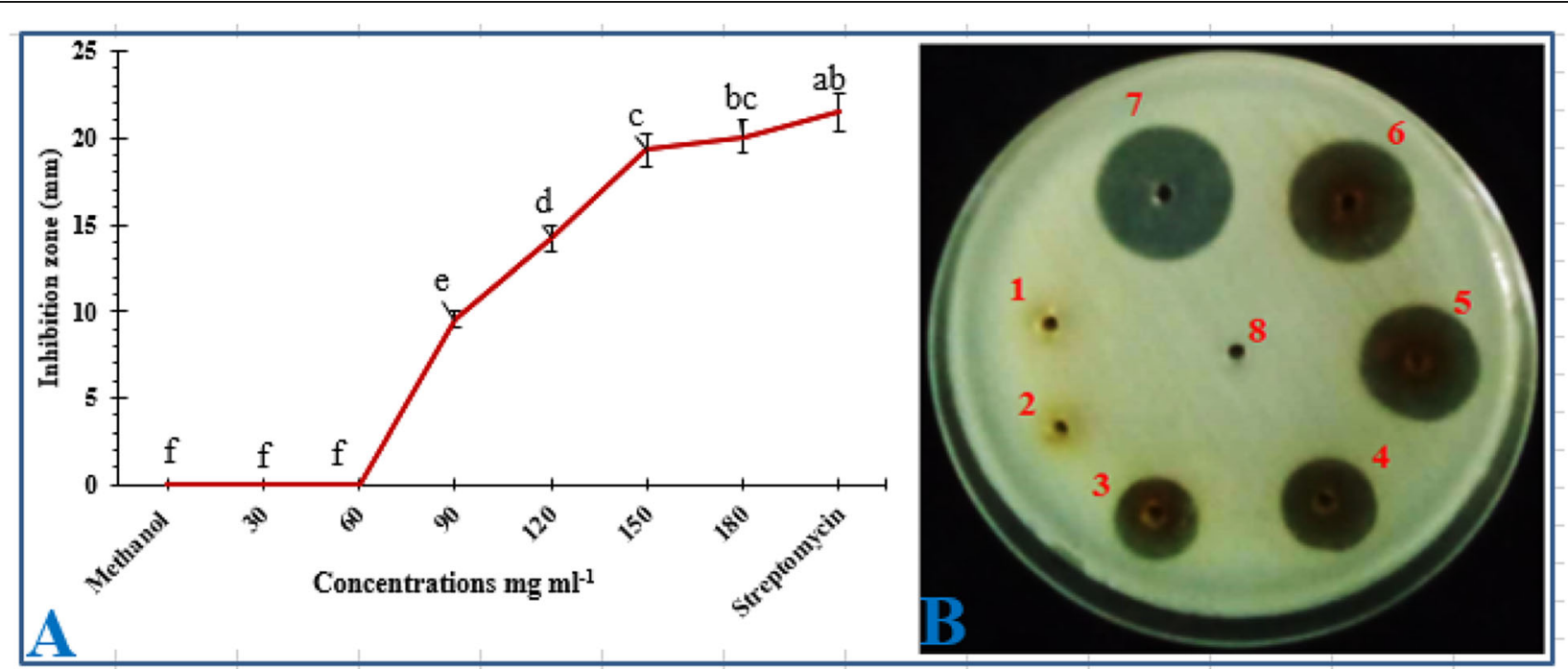

Fig. 1 Antibacterial potential of fungal metabolites against $R$. solanacearum. a Graphical presentation of data regarding zone of inhibition (ZI) produced by different concentrations of fungal metabolites. b Nutrient agar plate showing Zl, 1: $30 \mathrm{mg} / \mathrm{ml}, 2: 60 \mathrm{mg} / \mathrm{ml}, 3: 90$ mg/ml, 4: $120 \mathrm{mg} /$ $\mathrm{ml}$, 5: $150 \mathrm{mg} / \mathrm{ml}$, 6: $180 \mathrm{mg} / \mathrm{ml}$, 7: Streptomycin, and 8: methanol 


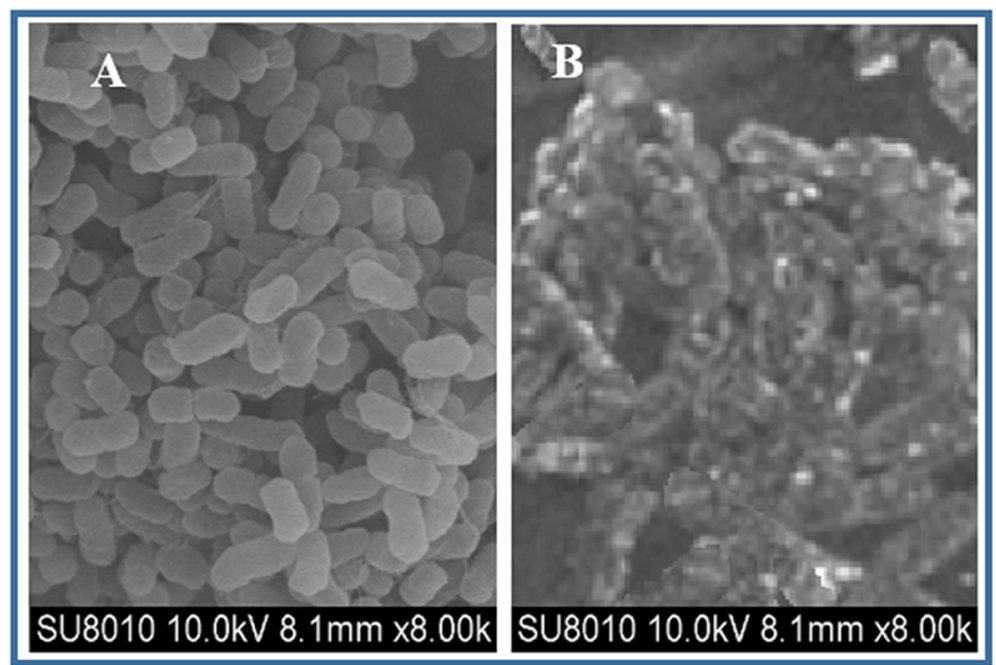

Fig. 2 Scanning electron images of R. solanacearum. a Control bacterial cells without treatment. b Bacterial cells treated with 9\% fungal metabolites

\section{In planta study}

\section{Progressive curve of diseased area}

Disease severity on the tomato plants inoculated with $R$. solanacearum was checked under the influence of fungal metabolites applications. Results indicated that fungal extract significantly affected the severity of the disease on tomato plants. The control plants that were not treated by the fungal extract exhibited highest AUDPC values and the plants were completely died. In comparison to the control, the treated plants showed lower AUDPC values and improved plant growth. Generally, the higher concentration and longer application time caused lower AUDPC values. The plants treated with the highest concentration of fungal metabolites (9\%), applied at 6 DBT, showed the lowest AUDPC value of 1140 , followed by 1260 produced by $9 \%$ of fungal extract applied at 3 DBT. Among treatments, the lowest concentration of $3 \%$ was applied at 0 DBT showed more disease severity and the highest AUDPC value 1790 (Fig. 3). More vigorous growth and lower soil population of $R$. solanacearum caused by the highest concentration of fungal extract resulted in lower AUDPC value. The fungal extract directly killed the bacteria in the soil due to which the plant was not attacked by bacteria and showed lower severity of the disease. In addition, crude extract improved plant growth and healthy plants showed resistant to pathogen attack resulting in lower AUDPC values. The improved plant growth might be due to the more production of plant growth promoting hormones such as gibberellins that help in starch accumulation (Konappa et al. 2020). The soil application of $B$. amyloliquefaciens inhibited bacterial wilt in tomato and reduced disease severity because of overproduction of antibiotics by induction of systemic resistance (Yamamoto et al. 2015).

\section{Soil bacterial population}

Tomato plants were inoculated by a known concentration of $R$. solanacearum in equal volume through soil, following the application of fungal metabolites in different concentrations and application times. The bacterial population was counted per gram of soil at the start and the end of the experiment. The difference in bacterial population from start to end was considered as decrease in soil bacterial population and expressed as $\log \mathrm{cfu} / \mathrm{g}$ of soil. The results showed that fungal extracts caused a significant reduction in soil bacterial population. Increase in concentration resulted in decreasing soil population of $R$. solanacearum (Table 1). The highest decrease in bacterial count (1.526 log cfu/g) of soil was achieved by $9 \%$ fungal metabolites applied at 6 DBT. Next best results were shown by $9 \%$ fungal metabolites applied at 3 DBT that gave $22.4 \mathrm{log} \mathrm{cfu} / \mathrm{g}$ decrease in pathogen soil population, while $3 \%$ fungal extract applied at 0 DBT exhibited lowest decrease $(0.686 \log \mathrm{cfu} / \mathrm{g})$ of soil in bacterial population among all treatments. The decrease in soil bacterial population by fungal extract is due to the presence of antibacterial compounds present in the extract. Several antibacterial compounds from Trichoderma spp. were reported that significantly suppress the growth of plant pathogenic bacteria. Lysosime, viridiofungin, and trichokonin produced by $T$. harzianum and other Trichoderma spp. are the key secondary metabolites reported to have antibacterial effect against plant pathogenic bacteria such as C. michiganensis, E. amylovora (Utkhede and Koch 2004; Xiao-yan et al. 2006; El-Hasan et al. 2009). The in vitro investigation also confirmed the direct killing of bacterial cells in which fungal extract showed a strong antibacterial activity by producing bigger inhibition zones. As discussed above, the antibacterial compounds affect the bacterial population in a variety of mechanisms including 


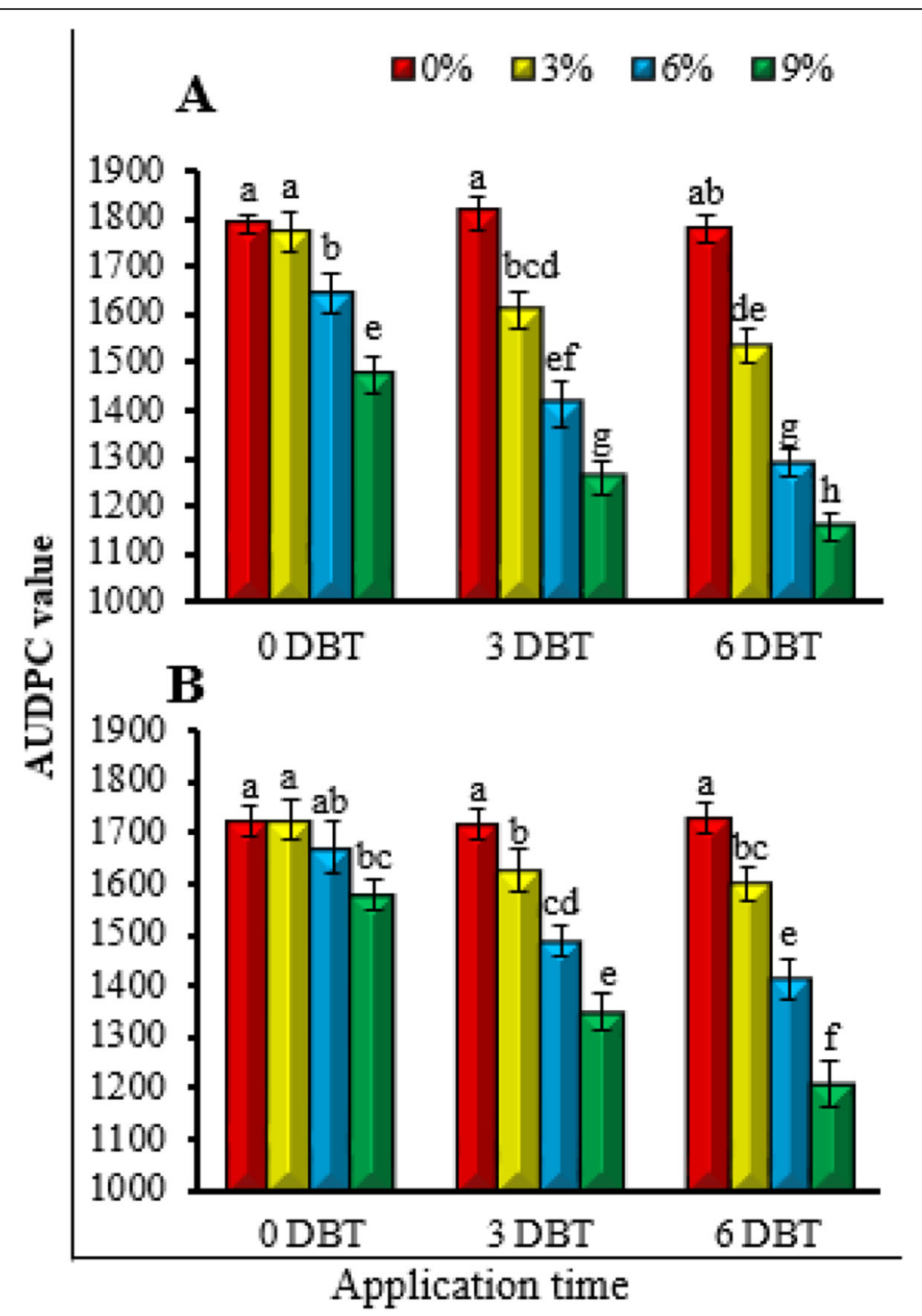

Fig. 3 Effect of fungal metabolites on AUDPC values of bacterial wilt in tomato plants inoculated with $R$. solanacearum. Each value is a mean \pm SD. Treatments having significant differences on the basis of LSD test have different lettering. a Experiment I. $\mathbf{b}$ Experiment II. Both experiments I and II are the same repeated experiments without any modification. DBT, days before transplantation

membranes, DNA and protein destructions (Tanaka et al. 2006; Zhang et al. 2008; Al-Obaidi 2014). This direct toxic effect of fungal metabolites contributes largely to cause a higher decrease in soil bacterial population. The fungal extract was prepared on simple wheat media. The extract was active at low concentration and effectively reduced soil bacterial population and improved plant growth. These characteristics make the use of this method as a low-cost disease management tool against bacterial wilt of tomato.

\section{Plant growth}

Both times of application as well as different doses of the fungal extract differed significantly in terms of enhancing plant growth parameters such as plant height, root length, and fresh biomass (Table 2). All growth parameters seemed to be dose-dependent and increased with increasing doses and time of application. The highest dose and longest application time exhibited best plant growth. The maximum plant height $(48.3 \mathrm{~cm})$, root length $(27.4 \mathrm{~cm})$, and fresh biomass $(54.3 \mathrm{~g})$ were obtained when $9 \%$ fungal extract was applied at $6 \mathrm{DBT}$, followed by the application of fungal extract at the same rate (9\%), but 3 DBT gave $42.6 \mathrm{~cm}, 23.6 \mathrm{~cm}$, and $47.3 \mathrm{~g}$ plant heights, root length and fresh biomass, respectively. The lowest values for plant growth parameters were recorded in case of control $(0 \%)$, where fungal extract was not applied. In planta experiment was repeated 
Table 1 Effect of fungal metabolites on decrease in soil bacterial population of $R$. solanacearum

\begin{tabular}{llll}
\hline $\begin{array}{l}\text { Application } \\
\text { time (DBT) }\end{array}$ & $\begin{array}{l}\text { Concentration } \\
(\%)\end{array}$ & \multicolumn{2}{c}{ Decrease in pathogen population } \\
\cline { 3 - 4 } & 0 & $0.671 \pm 0.005 \mathrm{~g}$ & $0.781 \pm 0.007 \mathrm{~h}$ \\
\hline 0 & 3 & $0.686 \pm 0.003 \mathrm{~g}$ & $0.836 \pm 0.009 \mathrm{~h}$ \\
& 6 & $0.866 \pm 0.009 \mathrm{f}$ & $1.073 \pm 0.004 \mathrm{fg}$ \\
& 9 & $1.193 \pm 0.008 \mathrm{~cd}$ & $1.276 \pm 0.006 \mathrm{~cd}$ \\
3 & 0 & $0.686 \pm 0.007 \mathrm{~g}$ & $0.789 \pm 0.003 \mathrm{~h}$ \\
& 3 & $0.832 \pm 0.004 \mathrm{f}$ & $0.973 \pm 0.007 \mathrm{fgh}$ \\
& 6 & $1.092 \pm 0.005 \mathrm{de}$ & $1.236 \pm 0.005 \mathrm{de}$ \\
& 9 & $1.365 \pm 0.009 \mathrm{~b}$ & $1.398 \pm 0.007 \mathrm{~b}$ \\
& 0 & $0.691 \pm 0.007 \mathrm{~g}$ & $0.797 \pm 0.007 \mathrm{~h}$ \\
& 3 & $0.963 \pm 0.007 \mathrm{ef}$ & $1.196 \pm 0.003 \mathrm{ef}$ \\
& 6 & $1.284 \pm 0.004 \mathrm{bc}$ & $1.383 \pm 0.006 \mathrm{bc}$ \\
& 9 & $1.526 \pm 0.010 \mathrm{a}$ & $1.591 \pm 0.009 \mathrm{a}$ \\
\hline
\end{tabular}

Each value is a mean \pm SD. Treatments having significant differences on the basis of LSD test have different lettering within a column. Both experiments I and II are the same repeated experiments without any modification. DBT days before transplantation

once without any modification and similar results were noticed. The treatments significantly increased plant growth than the control. The highest dose of the fungal extract and longest application period showed best results in repeated experiment (Table 3).

Results from in planta trail showed that soil application of fungal extract in different concentrations improved plant growth. Higher dose was more active than lower one. This is obviously because the higher dose had more antibacterial metabolites than lower dose, consequently giving better results. The longer application time helped in thorough mixing as well as increasing stability and compatibility of fungal metabolites in the soil, which resulted in increased activity of the extract. Obtained results are in line with the findings of Khan et al. (2019), who used organic soil amendment with different application times for the management of $R$. solanacearum in tomato and suggested that the longer application time exhibited best results because it increased stability and compatibility of the treatments that releases more antimicrobial compounds in the soil. Trichoderma spp. are prominent producers of metabolites having multiple biological activities including plant growth promotion effects (Ghisalberti 2002; Reino et al. 2008).

Production of antibiotics is usually related to the ability of biological control, and it has been found that utilization of metabolic products of fungal metabolites exhibited similar results on pathogen and host as those obtained with the corresponding live microorganisms (Vinale et al. 2008). Along with direct antagonistic or parasitic activity against pathogenic microbes, Trichoderma spp. also secrete various antimicrobial compounds that alter the host metabolism positively and affect its development and growth. Benitez et al. (2004) reported that plant seeds, when exposed to conidia of Trichoderma spp., exhibited increased productivity which suggested that metabolites from Trichoderma spp. can act as signaling compounds in addition to plant growth effect. Several Trichoderma strains are capable of producing secondary metabolites involving in auxin dependent mechanism to enhance root growth and increase plant biomass (Contreras-Cornejo et al. 2009; Hoyos-Carvajal et al. 2009). Recently, Konappa et al. (2020) reported the role of Trichoderma spp. in eliciting bacterial wilt resistance in tomato plants. Trichocaranes $\mathrm{A}, \mathrm{B}, \mathrm{C}$, and $\mathrm{D}$ produced by Trichoderma virens significantly affected growth of etiolated wheat coleoptiles

Table 2 Effect of fungal metabolites on the growth of tomato plants inoculated with $R$. solanacearum under greenhouse conditions (experiment I)

\begin{tabular}{|c|c|c|c|c|}
\hline Application time (DBT) & Concentration (\%) & Plant height $(\mathrm{cm})$ & Root length $(\mathrm{cm})$ & Fresh biomass $(\mathrm{g})$ \\
\hline \multirow[t]{4}{*}{$\overline{0}$} & 0 & $18.2 \pm 2.1 \mathrm{~g}$ & $10.2 \pm 1.2 \mathrm{hi}$ & $28.4 \pm 2.3 f$ \\
\hline & 3 & $17.5 \pm 1.5 \mathrm{~g}$ & $12.2 \pm 1.4 \mathrm{~g}$ & $27.2 \pm 2.1 \mathrm{f}$ \\
\hline & 6 & $21.3 \pm 2.2 \mathrm{fg}$ & $14.5 \pm 2.1 \mathrm{fg}$ & $28.3 \pm 2.8 f$ \\
\hline & 9 & $24.7 \pm 2.8 \mathrm{ef}$ & $16.4 \pm 1.4$ def & $34.1 \pm 2.0 \mathrm{de}$ \\
\hline \multirow[t]{4}{*}{3} & 0 & $17.5 \pm 2.1 \mathrm{~g}$ & $11.1 \pm 1.1 \mathrm{hi}$ & $28.2 \pm 2.6 f$ \\
\hline & 3 & $28.3 \pm 2.4 \mathrm{e}$ & $14.2 \pm 1.3 \mathrm{fgh}$ & $30.7 \pm 3.1$ ef \\
\hline & 6 & $34.3 \pm 2.6 d$ & $17.7 \pm 2.1 d$ & $35.4 \pm 2.8 d$ \\
\hline & 9 & $42.6 \pm 3.6 b$ & $23.6 \pm 1.8 b$ & $47.3 \pm 3.4 b$ \\
\hline \multirow[t]{4}{*}{6} & 0 & $17.0 \pm 1.6 \mathrm{~g}$ & $10.2 \pm 0.9 \mathrm{hi}$ & $29.6 \pm 2.8 f$ \\
\hline & 3 & $33.3 \pm 2.5 \mathrm{~d}$ & $18.6 \pm 1.4 \mathrm{~cd}$ & $34.4 \pm 2.6$ de \\
\hline & 6 & $40.5 \pm 2.8 \mathrm{bc}$ & $22.3 \pm 1.8 b c$ & $42.7 \pm 3.3 b c$ \\
\hline & 9 & $48.3 \pm 3.4 \mathrm{a}$ & $27.4 \pm 2.6 \mathrm{a}$ & $54.3 \pm 3.9 a$ \\
\hline
\end{tabular}

Each value is a mean \pm SD. Treatments having significant differences on the basis of LSD test have different lettering within a column. DBT days before transplantation 
Table 3 Effect of fungal metabolites on the growth of tomato plants inoculated with $R$. solanacearum under greenhouse conditions (experiment II)

\begin{tabular}{|c|c|c|c|c|}
\hline Application time (DBT) & Concentration (\%) & Plant height (cm) & Root length (cm) & Fresh biomass (g) \\
\hline \multirow[t]{4}{*}{0} & 0 & $15.2 \pm 1.3 \mathrm{gh}$ & $11.1 \pm 1.2 \mathrm{~g}$ & $25.3 \pm 2.1 \mathrm{f}$ \\
\hline & 3 & $16.3 \pm 2.1 \mathrm{gh}$ & $13.2 \pm 1.1 \mathrm{fg}$ & $25.4 \pm 1.7 f$ \\
\hline & 6 & $18.1 \pm 1.8 \mathrm{~g}$ & $14.3 \pm 1.1 \mathrm{f}$ & $26.2 \pm 2.7$ ef \\
\hline & 9 & $22.8 \pm 2.1 \mathrm{fg}$ & $18.4 \pm 1.8 \mathrm{~cd}$ & $30.3 \pm 2.3$ de \\
\hline \multirow[t]{4}{*}{3} & 0 & $16.1 \pm 1.7 \mathrm{gh}$ & $11.8 \pm 2.1 \mathrm{~g}$ & $26.4 \pm 1.6 f$ \\
\hline & 3 & $27.2 \pm 2.3 \mathrm{e}$ & $15.3 \pm 1.6 \mathrm{ef}$ & $29.3 \pm 2.1$ de \\
\hline & 6 & $33.3 \pm 2.6 d$ & $17.1 \pm 1.4 \mathrm{~d}$ & $34.4 \pm 2.8 \mathrm{C}$ \\
\hline & 9 & $42.6 \pm 3.7 b$ & $22.6 \pm 1.8 \mathrm{~b}$ & $43.2 \pm 3.1 b$ \\
\hline \multirow[t]{4}{*}{6} & 0 & $15.2 \pm 1.1 \mathrm{gh}$ & $11.6 \pm 1.0 \mathrm{~g}$ & $24.8 \pm 1.8 f$ \\
\hline & 3 & $32.4 \pm 2.8 d$ & $17.4 \pm 1.6$ de & $32.4 \pm 2.1 \mathrm{~cd}$ \\
\hline & 6 & $40.8 \pm 2.5 b c$ & $21.2 \pm 2.1 \mathrm{bc}$ & $41.1 \pm 2.9 b$ \\
\hline & 9 & $46.6 \pm 3.1 \mathrm{a}$ & $27.1 \pm 2.7 \mathrm{a}$ & $56.3 \pm 3.2 \mathrm{a}$ \\
\hline
\end{tabular}

Each value is a mean \pm SD. Treatments having significant differences on the basis of LSD test have different lettering within a column. $D B T$ days

before transplantation

(Macias et al. 2000). The direct toxic effect as well as plant growth-promoting effect of compounds present in the fungal metabolites collectively contributed to enhanced plant growth.

\section{Conclusion}

In this study, metabolites produced by the bio-control fungus $T$. harzianum were evaluated in the form of crude extract both in vitro and in planta in greenhouse experiments. The results showed that metabolites produced by T. harzianum had a strong antibacterial potential against $R$. solanacearum. Application of T. harzianum metabolites significantly improved growth of tomato plants by reducing disease severity and soil population of $R$. solanacearum. The metabolic extracts from T. harzianum could be used as efficient, low-cost, and environment-friendly approach to control $R$. solanacearum in tomato plants.

\section{Abbreviations}

SEM: Scanning electron microscopy; DBT: Days before transplantation; PDA: Potato dextrose broth; AUDPC: Area under disease progressive curve; CRD: Completely randomized design; LSD: Least significant difference; IZ: Inhibition zone; DNA: Deoxyribose nucleic acid; SD: Standard deviation

\section{Acknowledgements}

Not applicable

\section{Authors' contributions}

LY conceived, designed, performed the experiments, collected the data, and wrote original draft. RAAK analyzed the data critically revised the manuscript for intellectual content. All authors read and approved the final manuscript.

\section{Funding}

Not applicable

Availability of data and materials

The data and materials of this study have been presented in the manuscript.
Ethics approval and consent to participate

Not applicable

Consent for publication

Not applicable

\section{Competing interests}

The authors declare that they have no competing interests.

Received: 23 September 2020 Accepted: 6 December 2020

Published online: 03 January 2021

\section{References}

Abdel-Monaaim MF, Abo-Elyousr KM, Morsy KM (2011) Effectiveness of plant extracts on suppression of damping-off and wilt diseases of lupine (Lupinustermis forsik). Crop Prot 30:185-191 https://doi.org/10.1016/j.cropro. 2010.09.016

Al-Obaidi O (2014) Studies on antibacterial and anticancer activity of Nerium oleander extracts. Eur Chem Bull 3:259-262 https://doi.org/10.17628/ecb.2014. 3.259-262

Aloyce A, Ndakidemi PA, Mbega ER (2017) Identification and management challenges associated with Ralstonia solanacearum (Smith), Causal Agent of Bacterial Wilt Disease of Tomato in Sub-Saharan Africa. Pak J Biol Sci 20:530542 https://doi.org/10.3923/pjbs.2017.530.542

Bailey KL, Lazarovits G (2003) Suppressing soil-borne diseases with residue management and organic amendments. Soil Till Res 72:169-180 https://doi. org/10.1016/S0167-1987(03)00086-2

Benitez T, Rincón AM, Limón MC, Codón AC (2004) Biocontrol mechanisms of Trichoderma strains. Int Microbiol 7:249-260 http://scielo.isciii.es/pdf/im/v7n4/ Benitez.pdf

Contreras-Cornejo HA, Macias-Rodrìuez L, Cortés-Penagos C, López-Bucio J (2009) Trichoderma virens, a plant beneficial fungus, enhances biomass production and promotes lateral root growth through an auxin-dependent mechanism in Arabidopsis. PI Physiol 149:1579-1592 https://doi.org/10.1104/ pp.108.130369

El-Hasan A, Walker F, Schöne J, Buchenauer H (2009) Detection of viridiofungin A and another antifungal metabolites excreted by Trichoderma harzianum active against different plant pathogens. Eur J PI Pathol 124:457-470 https:// doi.org/10.1007/s10658-009-9433-3

Gal-hemed I, Atanasova I, Komo-zelazowsla M, Druzhinina IS, Viterbo A, Yarden O (2011) Marine isolates of Trichoderma spp. as potential halotolerant agents of biologicla control for Arid-zone agriculture. Appl Env Microbiol 77:5100-5109 https://doi.org/10.1128/AEM.00541-11 
Ghisalberti EL (2002) Anti-infective agents produced by the hyphomycetes genera Trichoderma and Glioclaudium. Curr Med Chem 1:343-374 https://doi. org/10.2174/1568012023354695

Gomez KA, Gomez AA (1984) Statistical Procedures for Agricultural Research. Wiley, New York

Goszczynska T, Serfontein JJ, Serfontein S (2000) Media and diagnostic tests, Introduction to practical Phytobacteriology, Bacterial Diseases Unit, ARC-Plant Protection Research Institute, Pretoria, South Africa, pp 60-73

Gruter D, Schmid B, Brandl H (2006) Influence of plant diversity and elevated atmospheric carbon dioxide levels on below ground bacterial diversity. BMC Microbiol 6:68 https://doi.org/10.1186/1471-2180-6-68

Hoyos-Carvajal L, Orduz S, Bissett J (2009) Growth stimulation in bean (Phaseolus vulgaris L.) by Trichoderma. Biol Cont 51:409-416 https://doi.org/10.1016/j. biocontrol.2009.07.018

Huet G (2014) Breeding for resistances to Ralstonia solanacearum. Front Plant Sci 5:715 https://doi.org/10.3389/fpls.2014.00715

Hyde KD, Soytong K (2008) The fungal endophyte dilemma. Fungal Divers 33:e173

Kamonwannasit S, Nantapong N, Kumkrai P, Luecha P, Kupittayanant S, Chudapongse N (2013) Antibacterial activity of Aqularia crassna leaf extract against Staphylococcus epidermis by disruption of cell wall. Ann Clin Microbiol Antimicrob 12:20 http://www.ann-clinmicrob.com/content/12/1/20

Kariuki CK, Mutitu EW, Muiru WM (2020) Effect of Bacillus and Trichoderma species in the management of the bacterial wilt of tomato (Lycopersicum esculentum) in the field. Egypt J Biol Pest Control 30:109 https://doi.org/10.1186/s41938020-00310-4

Khan RAA, Bilal A, Musharaf A, Asad A, Ishrat N, Muhammad F (2019) Management of Ralstonia solanacearum (Smith) Yabuuchi wilt in tomato (Solanum Lycopersicum L.) with dried powder of the medicinal plant Withania somnifera (L.) Dunal. Pak J Bot 51:297-306 https://doi.org/10.30848/ PJB2019-1(8

Khan RAA, Najeeb S, Mao Z, Jian L, Yuhong Y, Yan L, Bingyan X (2020) Bioactive secondary metabolites from Trichoderma spp. against phytopathogenic bacteria and Root-knot nematode. Microorganisms 8:401 https://doi.org/10. 3390/microorganisms8030401

Konappa N, Krishnamurthy S, Arakere UC (2020) Efficacy of indigenous plant growth-promoting rhizobacteria and Trichoderma strains in eliciting resistance against bacterial wilt in a tomato. Egypt J Biol Pest Control 30:106 https://doi.org/10.1186/s41938-020-00303-3

Macias FA, Varela RM, Simonet AM, Cutler HG, Cutler SJ, Eden MA, Hill RA (2000) Bioactive carotanes from Trichoderma virens. J Nat Prod 63:1197-1200 https:// doi.org/10.1021/np000121C

Madden LV, Hughes G, Van den B (2007) The study of plant disease epidemics. APS press, Minnesota. https://apsjournals.apsnet.org/doi/pdf/10.1094/ 9780890545058.fm

McDonald BA, Linde C (2002) Pathogen population genetics, evolutionary potential, and durable resistance. Annu Rev Phytopathol 40:349-379 https:// doi.org/10.1146/annurev.phyto.40.120501.101443

Mohamed BFF, Sallam NMA, Alamri SAM (2020) Approving the biocontrol method of potato wilt caused by Ralstonia solanacearum (Smith) using Enterobacter cloacae PS14 and Trichoderma asperellum T34. Egypt J Biol Pest Control 30:61 https://doi.org/10.1186/s41938-020-00262-9

Monte E (2001) Understanding Trichoderma: between agricultural biotechnology and microbial ecology. Int Microbiol 4:1-4 http://revistes.iec.cat/index.php/ IM/article/viewFile/9297/9293

Najeeb S, Ahmad M, Khan RAA, Naz I, Ali A, Alam SS (2019) Management of bacterial wilt in tomato using dried powder of Withania coagulan $(\mathrm{L})$ Dunal. Austral Plant Pathol 48:183-192 https://doi.org/10.1007/s13313-019-0618-8

Reino JL, Guerrero RF, Hernández-Galán R, Collado IG (2008) Secondary metabolites from species of the biocontrol agent Trichoderma. Phytochem Rev 7:89-123 https://doi.org/10.1007/s11101-006-9032-2

Saito H, Sakakibara Y, Sakata A, Kurashige R, Murakami D, Kageshima H, Saito A, Miyazaki Y (2019) Antibacterial activity of lysozyme-chitosan oligosaccharide conjugates (LYZOX) against Pseudomonas aeruginosa, Acinetobacter baumannii and Methicillin-resistant Staphylococcus aureus. PloS one 14: e0217504 https://doi.org/10.1371/journal.pone.0217504

Scherf JM, Milling A, Allen C (2010) Moderate temperature fluctuations rapidly reduce the viability of Ralstonia solanacearum race 3 , biovar 2 , in infected geranium, tomato, and potato plants. Appl Environ Microbiol 76:7061-7067 https://doi.org/10.1128/AEM.01580-10
Tajul MI, Sariah M, Latif MA, Toyota K (2011) Effect of cold-water irrigation on bacterial wilt pathogen of tomato. Int J Pest Manag 57:341-345 https://doi. org/10.1080/09670874.2011.617134

Tanaka JCA, da Silva CC, de Oliveira AJB, Nakamura CV, Dias BP (2006) Antibacterial activity of indole alkaloids from Aspidosperma ramiflorum. Braz J Med Biol Res 39:387-391 https://doi.org/10.1590/50100-879X2006000300009

Tong X, Shen XY, Hou CL (2018) Antimicrobial activity of fungal endophytes from Vaccinium dunalianum var. urophyllum. Sains Malaysiana 47:1685-1692 http:// www.ukm.my/jsm/pdf_files/SM-PDF-47-8-2018/07\%20Xin\%20Tong.pdf

Utkhede R, Koch C (2004) Biological treatments to control bacterial canker of greenhouse tomatoes. Biocontrol 49:305-313 https://doi.org/10.1023/B:BICO. 0000025373.69584 .08

Vinale F, Sivasithamparam K, Ghisalberti EL, Marra R, Woo SL, Lorito M (2008) Trichoderma-plant pathogen interactions. Soil Biol \& Biochem 40:1-10 https://doi.org/10.1016/j.soilbio.2007.07.002

Vizcaino A, Sanz L, Basilio A (2006) Screening of antimicrobial activities in Trichoderma isolates representing three Trichoderma sections. Mycol Res 109: 1397-1406 https://doi.org/10.1017/S0953756205003898

Xiao-yan S, Qing-tao S, Shu-tao X, Xiu-lan C, Cai-yan S, Yu-zhong Z (2006) Broadspectrum antimicrobial activity and high stability of Trichokonins from Trichoderma koningii SMF2 against plant pathogens. FEMS. Microbiol Let 260:119-125 https://doi.org/10.1111/j.1574-6968.2006.00316.x

Yamamoto S, Shiraishi S, Kawagoe Y, Mochizuki M, Suzuki S (2015) Impact of Bacillus amyloliquefaciens S13-3 on control of bacterial wilt and powdery mildew in tomato. Pest Manag Sci 71:722-727 https://doi. org/10.1002/ps.3837

Yuliar NYA, Toyota K (2015) Recent trends in control methods for bacterial wilt diseases caused by Ralstonia solanacearum. Microbes Environ 30:1-11 https:// doi.org/10.1264/jsme2.ME14144

Zhang L, Kong Y, Wu D, Zhang H, Wu J, Chen J, Ding J, Hu L, Jiang H, Shen X (2008) Three flavonoids targeting the beta-hydroxyacyl-acyl carrier protein dehydratase from Helicobacter pylori: crystal structure characterization with enzymatic inhibition assay. Protein Sci 17:1971-1978 https://doi.org/10.1110/ ps.036186.108

\section{Publisher's Note}

Springer Nature remains neutral with regard to jurisdictional claims in published maps and institutional affiliations.

\section{Submit your manuscript to a SpringerOpen ${ }^{\circ}$ journal and benefit from:}

- Convenient online submission

Rigorous peer review

- Open access: articles freely available online

- High visibility within the field

- Retaining the copyright to your article

Submit your next manuscript at $\boldsymbol{\nabla}$ springeropen.com 